\title{
Distribution of aminoglycoside resistance genes in recent clinical isolates of Enterococcus faecalis, Enterococcus faecium and Enterococcus avium
}

\author{
N. KOBAYASHI ${ }^{1 *}$, Md. MAHBUB ALAM ${ }^{1}$, Y. NISHIMOTO ${ }^{1}, \mathrm{~S}_{\text {. URASAWA }}^{1}$, \\ N. UEHARA ${ }^{2}$ AND N. WATANABE ${ }^{2}$ \\ ${ }^{1}$ Department of Hygiene, Sapporo Medical University School of Medicine, S-1, W-17, Chuo-ku, \\ Sapporo 060-8556, Japan \\ ${ }^{2}$ Department of Laboratory Diagnosis, Sapporo Medical University School of Medicine, S-1, W-16, \\ Chuo-ku, Sapporo 060-8543, Japan
}

(Accepted 21 November 2000)

\section{SUMMARY}

Aminoglycoside modifying enzymes (AMEs) are major factors which confer aminoglycoside resistance on bacteria. Distribution of genes encoding seven AMEs was investigated by multiplex PCR for 279 recent clinical isolates of enterococci derived from a university hospital in Japan. The $\operatorname{aac}\left(6^{\prime}\right)-\operatorname{aph}\left(2^{\prime \prime}\right)$, which is related to high level gentamicin resistance, was detected at higher frequency in Enterococcus faecalis (42.5\%) than in Enterococcus faecium (4.3\%).

Almost half of E. faecalis and E. faecium isolates possessed ant(6)-Ia and aph(3')-IIIa. The profile of AME gene(s) detected most frequently in individual strains of E. faecalis was aac $\left(6^{\prime}\right)$ $a p h\left(2^{\prime \prime}\right)+\operatorname{ant}(6)-I a+a p h\left(3^{\prime}\right)-I I I a$, and isolates with this profile showed high level resistance to both gentamicin and streptomycin. In contrast, AME gene profiles of $\operatorname{aac}\left(6^{\prime}\right)-\operatorname{Ii}+\operatorname{ant}(6)-$ $I a+a p h\left(3^{\prime}\right)-I I I a$, followed by $a a c\left(6^{\prime}\right)-I i$ alone, were predominant in E. faecium. Only one AME gene profile of ant(6)-Ia+aph(3')-IIIa was found in Enterococcus avium. The ant(4')-Ia and ant(9)-Ia, which have been known to be distributed mostly among Staphylococcus aureus strains, were detected in a few enterococcal strains. An AME gene $a p h\left(2^{\prime \prime}\right)-I c$ was not detected in any isolates of the three enterococcal species. These findings indicated a variety of distribution profiles of AME genes among enterococci in our study site.

\section{INTRODUCTION}

Enterococci are becoming an important cause of nosocomial infections including bacteraemia, surgical wound infection, and urinary tract infection in various regions of the world [1]. Recently, enterococci has become increasingly resistant to broad ranges of antimicrobial agents [2], particularly, glycopeptides, beta-lactams, and aminoglycosides. Among these antibiotics, high level aminoglycoside resistance is reported worldwide, while glycopeptide or betalactam-resistant enterococci are prevalent mostly in the United States and European countries [3]. The presence of high level aminoglycoside resistance

* Author for correspondence. results in the loss of synergy between cell wall synthesis inhibiting antibiotics (penicillins and glycopeptides) and aminoglycosides, which makes the treatment of serious enterococcal infections difficult [3]. Hence, epidemiologic survey of aminoglycoside resistance in enterococci is of significance for control of enterococcal infections.

Although enterococci are intrinsically resistant to low levels of aminoglycosides, high level resistance to aminoglycosides (MIC $\geqslant 2000 \mu \mathrm{g} / \mathrm{ml}$ ) is mostly due to acquisition of genes encoding aminoglycoside modifying enzymes (AMEs) [4,5]. The high level resistance to gentamicin, a key therapeutic aminoglycoside, in enterococci is associated with the aac ( $\left.6^{\prime}\right)$ $\operatorname{aph}\left(2^{\prime \prime}\right)$ which encodes the bifunctional AME, 
Table 1. Primers and their sequences used in multiplex PCR to detect genes of aminoglycoside modifying enzymes

\begin{tabular}{|c|c|c|c|c|c|c|}
\hline Gene & Enzyme & Primer sequence $\left(5^{\prime}-3^{\prime}\right)$ & Position* & $\begin{array}{l}\text { Size of PCR } \\
\text { product (bp) }\end{array}$ & $\begin{array}{l}\text { Reaction } \\
\text { number } \dagger\end{array}$ & $\begin{array}{l}\text { Reference of } \\
\text { AME gene } \\
\text { sequence }\end{array}$ \\
\hline $\operatorname{aac}\left(6^{\prime}\right)-I i$ & $\mathrm{AAC}\left(6^{\prime}\right)-\mathrm{I}$ & $\begin{array}{l}\text { tggccggaagaatatggaga } \\
\text { gcatttggtaagacacctacg }\end{array}$ & $\begin{array}{c}73-92 \\
462-482\end{array}$ & 410 & II & 7 \\
\hline $\operatorname{aac}\left(6^{\prime}\right)-\operatorname{aph}\left(2^{\prime \prime}\right)$ & $\mathrm{AAC}\left(6^{\prime}\right)-\mathrm{APH}\left(2^{\prime \prime}\right)$ & $\begin{array}{l}\text { ccaagagcaataagggcatacc } \\
\text { accetcaaaaactgttgttgc }\end{array}$ & $\begin{array}{c}424-445 \\
1078-1098\end{array}$ & 675 & I & 6 \\
\hline $\operatorname{ant}\left(4^{\prime}\right)-I a$ & $\operatorname{ANT}\left(4^{\prime}\right)-\mathrm{I}$ & $\begin{array}{l}\text { ggaagcagagttcagccatg } \\
\text { tgcetgcatattcaaacagc }\end{array}$ & $\begin{array}{l}180-199 \\
426-445\end{array}$ & 266 & I & 30 \\
\hline $\operatorname{ant}(6)-I a$ & ANT(6)-I & $\begin{array}{l}\text { cgggagaatgggagactttg } \\
\text { ctgtggctccacaatctgat }\end{array}$ & $\begin{array}{r}83-102 \\
626-645\end{array}$ & 563 & II & 31 \\
\hline $\operatorname{ant}(9)-I a$ & ANT(9)-I & $\begin{array}{l}\text { ggttcagcagtaaatggtggt } \\
\text { tgccacattcgagctagggtt }\end{array}$ & $\begin{array}{l}103-123 \\
557-578\end{array}$ & 476 & I & 32 \\
\hline $\operatorname{aph}\left(2^{\prime \prime}\right)-I c$ & $\mathrm{APH}\left(2^{\prime \prime}\right)-\mathrm{Ic}$ & $\begin{array}{l}\text { atacaatccgtcgagtcget } \\
\text { gttggecttatcetcttcca }\end{array}$ & $\begin{array}{c}61-80 \\
878-897\end{array}$ & 837 & II & 8 \\
\hline $\operatorname{aph}\left(3^{\prime}\right)-I I I a$ & $\mathrm{APH}\left(3^{\prime}\right)-\mathrm{III}$ & $\begin{array}{l}\text { ctgatcgaaaaataccgct } \\
\text { acaatccgatatgtcgatggag }\end{array}$ & $\begin{array}{c}37-55 \\
369-390\end{array}$ & 354 & I & 33 \\
\hline
\end{tabular}

* Position of primer sequence is expressed as nucleotide numbers from the first base of initiation codon of each AME gene. $\uparrow$ See text (Materials and Method).

$\operatorname{AAC}\left(6^{\prime}\right)-\mathrm{APH}\left(2^{\prime \prime}\right)[6]$. Kanamycin and streptomycin resistances in enterococci are mediated by $\mathrm{APH}\left(3^{\prime}\right)$ and ANT [6] enzymes encoded by aph(3')-IIIa and ant(6)-Ia, respectively [4]. Moderate level resistance to gentamicin and other aminoglycosides in E. faecium is conferred by AAC(6')-I and results in the marked decrease in penicillin-aminoglycoside synergism [7]. This AME gene is encoded by a chromosomal gene, aac( $\left.6^{\prime}\right)-I i$ in E. faecium [7]. Furthermore, aph(2")-Ic and $\operatorname{aph}\left(2^{\prime \prime}\right)$-Id which confer gentamicin resistance were recently identified in enterococci $[8,9]$. The $\operatorname{ant}\left(3^{\prime \prime}\right)-\operatorname{Ia}\left(\operatorname{ant}\left(3^{\prime \prime}\right)(9)\right.$ or aadAl) and $\operatorname{ant}\left(4^{\prime}\right)$-Ia gene, found in enterobacteria and Staphylococcus aureus, respectively, were also detected in a few enterococcal isolates $[10,11]$. Although the prevalence of high level resistance to gentamicin or $a a c\left(6^{\prime}\right)-a p h\left(2^{\prime \prime}\right)$ gene in enterococci has been reported in many studies [11-14], data on distribution of other AME genes in each enterococcal species are limited. In this study, to estimate the present status of aminoglycoside resistance in enterococci, we investigated distribution of seven AME genes in recent clinical isolates by multiplex PCR.

\section{MATERIALS AND METHOD}

\section{Bacterial strains, identification and characterization}

A total of 279 strains comprising 226 E. faecalis strains, 46 E. faecium strains, and 7 E. avium strains were analysed. These bacterial strains were isolated from clinical specimens of 259 patients in Sapporo Medical University Hospital, Sapporo, Japan between January 1997 and December 1998. Approximately $50 \%$ of the isolates were derived from urine, followed by other samples such as pus, bile, sputum, vaginal secretion, and gastric juice, while isolates from blood sample were only six strains. Identification of bacterial species and antimicrobial susceptibility tests were performed by the use of MicroScan WalkAway ${ }^{\mathrm{TM}}-96$ (Baxter Diagnostics, Inc., West Sacrament, USA), and rapid ID32 STREP (bioMerieux) was also employed for several isolates. Identification of some E. faecalis and E. faecium strains were confirmed also by detecting with PCR enterococcal PBP5 genes, which are distinct between the two species $[15,16]$, using $E$. faecalis specific primers (5'-CAGGGATTCAAGCAGAAGGA-3' and 5'-TCACTGGTTCAGAAGCGACTG-3') and E. faecium specific primers (5'GATGAATACCTCATTAGGTGA-3' and 5'-TGGTTGTTCAGGATTTTCTTC-3').

During the study period, no vancomycin-resistant enterococcus was detected. MIC of the following aminoglycosides, gentamicin (GM), tobramycin (TOB), sisomicin (SISO), kanamycin (KM), streptomycin (SM) and spectinomycin (SPCM), were measured by broth microdilution assay as recommended by NCCLS [17].

E. faecalis strains were genetically typed by arbitrarily primed PCR (AP-PCR) using ERIC2 primer, as described previously [18]. 


\section{Multiplex PCR for detection of AME genes}

In this study, multiplex PCR was employed to detect seven AME genes which have been reported to be distributed among enterococci and staphylococci $[4,8,11,19]$. AME genes examined were $\operatorname{aac}\left(6^{\prime}\right)-I i$,

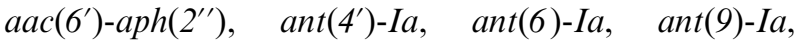
$\operatorname{aph}\left(2^{\prime \prime}\right)-I c$, and $\operatorname{aph}\left(3^{\prime}\right)-I I I a$. Among these, the ant(9)$I a$ has been detected only in S. aureus (4). The ant(4')$I a$ gene is also prevalent in $S$. aureus and has been reported only in a few enterococcal strains $[11,20]$. AME genes such as $\operatorname{aac}\left(6^{\prime}\right)-a p h\left(2^{\prime \prime}\right), \operatorname{aph}\left(3^{\prime}\right)-I I I a$, and $\operatorname{ant}\left(3^{\prime \prime}\right)(9)$ have been found in both $S$. aureus and enterococci $[4,10]$. PCR primers specific for each AME gene are listed in Table 1. Multiplex PCR was carried out using two reaction tubes for a single bacterial isolate. In the reaction $\mathrm{I}$, four pairs of primers specific for $\operatorname{aac}\left(6^{\prime}\right)-\operatorname{aph}\left(2^{\prime \prime}\right)$, $\operatorname{ant}\left(4^{\prime}\right)-\operatorname{Ia}$, $\operatorname{ant}(9)$ $I a$, and $a p h\left(3^{\prime}\right)-I I I a$ were contained and the reaction II tube contained three primer pairs for $a a c\left(6^{\prime}\right)-I i$, ant (6)$I a$, and $a p h\left(2^{\prime \prime}\right)-I c$. These primers were designed to produce DNA fragments with distinct sizes from target AME genes in each reaction tube. Bacterial DNA was extracted using achromopeptidase as described previously [21]. Reaction mixture $(100 \mu 1)$ containing $1 \mu \mathrm{l}$ template bacterial DNA, 2.5 unit of AmpliTaq DNA polymerase (Perkin-Elmer), $200 \mu \mathrm{M}$ each of dNTP, 30 pM each of primer, $10 \mathrm{~mm}$ Tris-HCl (pH 8.3), $50 \mathrm{~mm} \mathrm{KCl}$, and $1.5 \mathrm{~mm} \mathrm{MgCl}_{2}$ were subjected to 30 PCR cycles of denaturation $\left(94^{\circ} \mathrm{C}\right.$, $1 \mathrm{~min})$, annealing $\left(55^{\circ} \mathrm{C}, 1 \mathrm{~min}\right)$, and primer extension $\left(72{ }^{\circ} \mathrm{C}, 2 \mathrm{~min}\right)$ in Thermal Cycler. The PCR products were analysed by electrophoresis on $1 \%$ agarose gel stained with ethidium bromide.

\section{RESULTS}

Using multiplex PCR with 3 or 4 primer pairs designed in this study, individual AME gene-specific PCR products were generated and multiple PCR products in each reaction tube were clearly discriminated by their size, as shown in Figure 1. Detection rate of each AME gene were summarized in Table 2. The aac $\left(6^{\prime}\right)$ $\operatorname{aph}\left(2^{\prime \prime}\right)$ gene was more frequently found in E. faecalis $(42.5 \%)$ than in E. faecium $(4.3 \%)$. In contrast, $a a c\left(6^{\prime}\right)-I i$ was detected exclusively and commonly in E. faecium. In both E. faecalis and E. faecium, almost half isolates possessed ant(6)-Ia and aph(3')-IIIa. The ant $\left(4^{\prime}\right)$-I $a$ was detected in four $E$. faecalis strains, and ant(9)-Ia was detected in a single strain each of $E$. faecalis and E. faecium. In E. avium, only two isolates
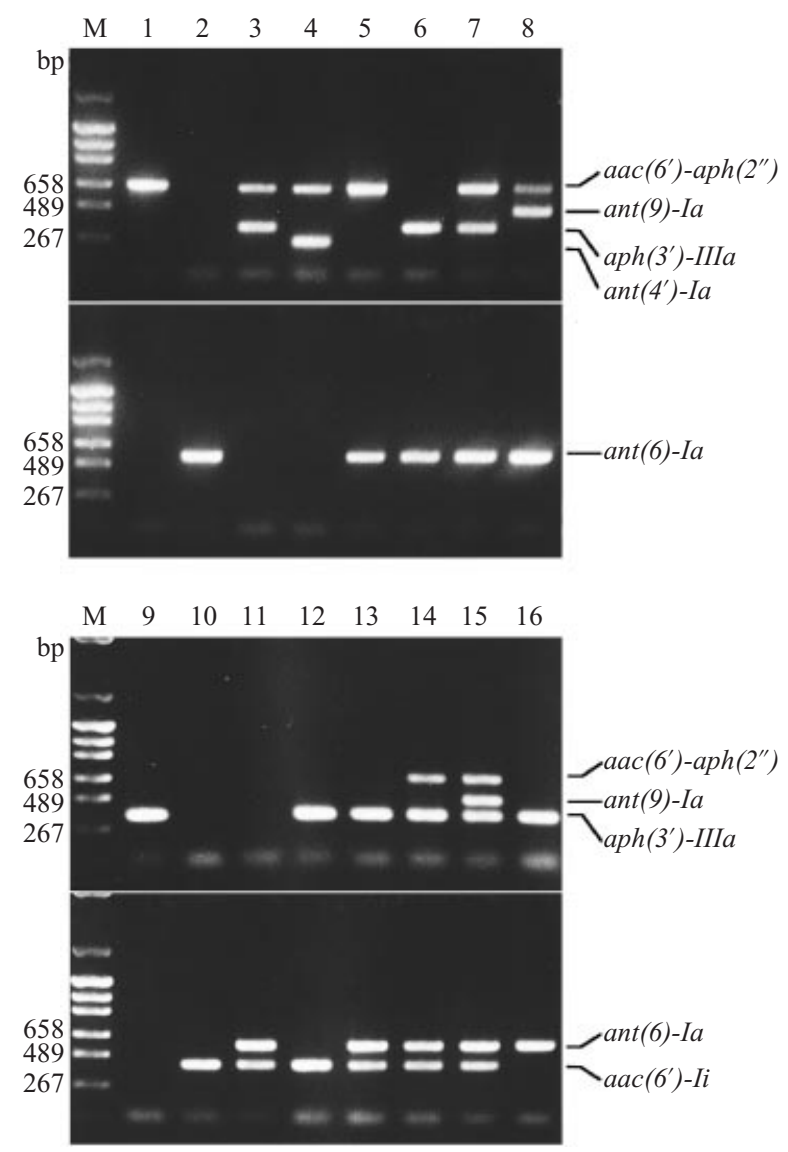

Fig. 1. Amplified products of AME genes generated by multiplex PCR, reactions I (upper portion) and II (lower portion), from enterococci with representative AME gene profiles. M, DNA size marker, lanes 1-9, E. faecalis strains (e69, e92, e282, e97, e6, e21, e308, e269, e216, respectively); lanes 10-15, E. faecium strains (e129, e100, e30, e137, e136, e185, respectively); lane 16, E. avium strain, e149.

possessed ant(6)-Ia and aph(3')-IIIa, although the number of isolates was small. The $\operatorname{aph}\left(2^{\prime \prime}\right)-I c$, which was described recently as a novel GM resistance gene [8], was not detected in any enterococci.

Table 3 shows detection profiles of AME genes (AME gene pattern). In E. faecalis, $52 \cdot 2 \%$ of isolates was found to have any AME gene. The most frequently observed AME gene profile was aac $\left(6^{\prime}\right)$ $a p h\left(2^{\prime \prime}\right)+\operatorname{ant}(6)-I a+a p h\left(3^{\prime}\right)-I I I a$ found in $35 \cdot 8 \%$ of $E$. faecalis isolates. This AME gene profile was found more frequently detected in E. faecalis strains derived from blood $(75 \%, 3 / 4)$, bile $(67 \%, 6 / 9)$ and pus $(53 \%, 9 / 17)$ than in those from urine $(36 \%, 43 / 119)$, gastric juice $(21 \%, 5 / 24)$, vaginal secretion $(17 \%$, $2 / 12)$, sputum and pharyngeal swab $(20 \%, 2 / 8)$ and all other specimens $(31 \%, 11 / 35)$. When clonality of E. faecalis was analysed by AP-PCR, the enterococci with this major AME gene profile were differentiated 
Table 2. Incidence of aminoglycoside modifying enzyme (AME) genes in each enterococcal species

\begin{tabular}{lccl}
\hline \hline \multicolumn{4}{c}{ AME gene-positive isolates $(\%)$} \\
\cline { 2 - 4 } AME gene & $\begin{array}{l}\text { E. faecalis } \\
(226 \text { isolates })\end{array}$ & $\begin{array}{l}\text { E. faecium } \\
(46 \text { isolates })\end{array}$ & $\begin{array}{l}\text { E. avium } \\
(7 \text { isolates })\end{array}$ \\
\hline aac $\left(6^{\prime}\right)-I i$ & $0(0)$ & $46(100)$ & $0(0)$ \\
$\operatorname{aac}\left(6^{\prime}\right)-a p h\left(2^{\prime \prime}\right)$ & $92(42 \cdot 5)$ & $2(4 \cdot 3)$ & $0(0)$ \\
$\operatorname{ant}\left(4^{\prime}\right)-I a$ & $4(1 \cdot 8)$ & $0(0)$ & $0(0)$ \\
$\operatorname{ant}(6)-I a$ & $105(46 \cdot 5)$ & $27(58 \cdot 7)$ & $2(28 \cdot 6)$ \\
$\operatorname{ant}(9)-I a$ & $1(0 \cdot 4)$ & $1(2 \cdot 1)$ & $0(0)$ \\
$\operatorname{aph}\left(2^{\prime \prime}\right)-I c$ & $0(0)$ & $0(0)$ & $0(0)$ \\
$\operatorname{aph}\left(3^{\prime}\right)-I I I a$ & $103(45 \cdot 6)$ & $23(50 \cdot 0)$ & $2(28 \cdot 6)$ \\
\hline \hline
\end{tabular}

Table 3. Profiles of aminoglycoside modifying enzyme (AME) genes and their incidence in each enterococcal species

\begin{tabular}{|c|c|c|}
\hline Enterococcal species & AME gene profile & No. of isolates $(\%)$ \\
\hline E. faecalis (226 isolates) & $\begin{array}{l}\text { AME gene-negative } \\
\operatorname{aac}\left(6^{\prime}\right)-\operatorname{aph}\left(2^{\prime \prime}\right) \\
\operatorname{ant}(6)-I a \\
\operatorname{aph}\left(3^{\prime}\right)-I I I a \\
\operatorname{aac}\left(6^{\prime}\right)-\operatorname{aph}\left(2^{\prime \prime}\right)+\operatorname{ant}\left(4^{\prime}\right)-I a \\
\operatorname{aac}\left(6^{\prime}\right)-\operatorname{aph}\left(2^{\prime \prime}\right)+\operatorname{ant}(6)-I a \\
\operatorname{aac}\left(6^{\prime}\right)-\operatorname{aph}\left(2^{\prime \prime}\right)+\operatorname{aph}\left(3^{\prime}\right)-I I I a \\
\operatorname{ant}(6)-\operatorname{Ia}+\operatorname{aph}\left(3^{\prime}\right)-I I I a \\
\operatorname{aac}\left(6^{\prime}\right)-\operatorname{aph}\left(2^{\prime \prime}\right)+\operatorname{ant}(6)-I a+\operatorname{ant}(9)-I a \\
\operatorname{aac}\left(6^{\prime}\right)-\operatorname{aph}\left(2^{\prime \prime}\right)+\operatorname{ant}(6)-I a+\operatorname{aph}\left(3^{\prime}\right)-I I I a\end{array}$ & $\begin{aligned} & 108(47 \cdot 8) \\
& 5(2 \cdot 2) \\
& 2(0 \cdot 9) \\
& 2(0 \cdot 9) \\
& 4(1 \cdot 8) \\
& 3(1 \cdot 3) \\
& 2(0 \cdot 9) \\
& 18(8 \cdot 0) \\
& 1(0 \cdot 4) \\
& 81(35 \cdot 8)\end{aligned}$ \\
\hline E. faecium (46 isolates) & $\begin{array}{l}\operatorname{aac}\left(6^{\prime}\right)-I i \\
\operatorname{aac}\left(6^{\prime}\right)-I i+\operatorname{ant}(6)-I a \\
\operatorname{aac}\left(6^{\prime}\right)-I i+\operatorname{aph}\left(3^{\prime}\right)-I I I a \\
\operatorname{aac}\left(6^{\prime}\right)-I i+\operatorname{aph}(6)-I a+\operatorname{aph}\left(3^{\prime}\right)-I I I a \\
\operatorname{aac}\left(6^{\prime}\right)-I i+\operatorname{aac}\left(6^{\prime}\right)-\operatorname{aph}\left(2^{\prime \prime}\right)+\operatorname{ant}(6)-I a+\operatorname{aph}\left(3^{\prime}\right)-I I I a \\
\operatorname{aac}\left(6^{\prime}\right)-I i+\operatorname{aac}\left(6^{\prime}\right)-\operatorname{aph}\left(2^{\prime \prime}\right)+\operatorname{ant}(6)-I a+\operatorname{ant}(9)-I a+\operatorname{aph}\left(3^{\prime}\right)-I I I a\end{array}$ & $\begin{aligned} 18 & (39 \cdot 1) \\
5 & (10 \cdot 9) \\
1 & (2 \cdot 2) \\
20 & (43 \cdot 5) \\
1 & (2 \cdot 2) \\
1 & (2 \cdot 2)\end{aligned}$ \\
\hline E. avium (7 isolates) & $\begin{array}{l}\text { AME gene-negative } \\
a n t(6)-I a+a p h\left(3^{\prime}\right)-I I I a\end{array}$ & $\begin{array}{l}5(71 \cdot 4) \\
2(28 \cdot 6)\end{array}$ \\
\hline
\end{tabular}

into 18 genetic types containing a dominant type that accounted for almost half of the isolates (data not shown). In E. faecium, $60 \cdot 9 \%$ of isolates possessed one or more AME genes in addition to aac $\left(6^{\prime}\right)-I i$. The AME gene profile of $a a c\left(6^{\prime}\right)-I i+\operatorname{ant}(6)-I a+a p h\left(3^{\prime}\right)$ III $a$ was most frequently detected, followed by that of aac $\left(6^{\prime}\right)-I i$. Furthermore, it was of note that 4 or 5 AME genes including $a a c\left(6^{\prime}\right)-a p h\left(2^{\prime \prime}\right)$ were detected in the two E. faecium strains (e136, e185, Fig. 1).

MIC of aminoglycosides was measured for enterococcal strains with representative AME gene patterns in order to confirm consistency with their aminoglycoside resistance phenotype (Table 4). Most strains with $\operatorname{aac}\left(6^{\prime}\right)-\operatorname{aph}\left(2^{\prime \prime}\right)$ showed high level resistance (MIC $\geqslant 2000 \mu \mathrm{g} / \mathrm{ml}$ ) to $\mathrm{GM}$, as well as to SISO, KM, and TOB. Only one E. faecium strain (e136) with aac $\left(6^{\prime}\right)$ - $a p h\left(2^{\prime \prime}\right)$ exhibited moderate level resistance to GM, SISO, and TOB. E. faecium having aac (6')-Ii was moderately resistant to SISO and TOB, and strains with $\operatorname{aph}\left(3^{\prime}\right)-I I I a$ were highly resistant to KM. Strains with ant(6)-Ia and ant(9)-Ia were highly resistant to SM and SPCM, respectively. Thus, resistance to aminoglycosides of enterococcal strains were generally correlated with the presence of individual AME genes. However, the high level resistance to GM, SISO, KM, and TOB of E. faecium strain e129, SM resistance of $E$. faecium strain e30, and SPCM resistance of $E$. faecalis strain e 6 could not be explained by the AME genes detected in this study. As for these three strains, an attempt was made by PCR to detect other AME 
Table 4. MIC of aminoglycosides against enterococcal isolates with different profiles of aminoglycoside modifying enzyme (AME) genes

\begin{tabular}{|c|c|c|c|c|c|c|c|c|}
\hline \multirow{2}{*}{$\begin{array}{l}\text { Enterococcal } \\
\text { species }\end{array}$} & \multirow[b]{2}{*}{ Isolate } & \multirow[b]{2}{*}{ AME gene profile } & \multicolumn{6}{|c|}{$\mathrm{MIC}(\mu \mathrm{g} / \mathrm{ml})$} \\
\hline & & & GM & SISO & KM & тов & SM & SPCM \\
\hline \multirow[t]{14}{*}{ E. faecalis } & e66 & AME gene-negative & 8 & 4 & 16 & 4 & 64 & 32 \\
\hline & e69 & $\operatorname{aac}\left(6^{\prime}\right)-\operatorname{aph}\left(2^{\prime \prime}\right)$ & $>2048$ & $>2048$ & $>2048$ & $>2048$ & 128 & 32 \\
\hline & e92 & $\operatorname{ant}(6)-I a$ & 8 & 4 & 16 & 32 & $>2048$ & 32 \\
\hline & e216 & $\operatorname{aph}\left(3^{\prime}\right)-I I I a$ & 64 & 16 & $>2048$ & 32 & 128 & 128 \\
\hline & e97 & $a a c\left(6^{\prime}\right)-a p h\left(2^{\prime \prime}\right)+\operatorname{ant}\left(4^{\prime}\right)-I a$ & $>2048$ & $>2048$ & $>2048$ & $>2048$ & 128 & 64 \\
\hline & e150 & $\operatorname{aac}\left(6^{\prime}\right)-\operatorname{aph}\left(2^{\prime \prime}\right)+\operatorname{ant}\left(4^{\prime}\right)-I a$ & $>2048$ & $>2048$ & $>2048$ & $>2048$ & 128 & 64 \\
\hline & e6 & $\operatorname{aac}\left(6^{\prime}\right)-\operatorname{aph}\left(2^{\prime \prime}\right)+\operatorname{ant}(6)-I a$ & $>2048$ & $>2048$ & $>2048$ & $>2048$ & $>2048$ & $>2048$ \\
\hline & e139 & $a a c\left(6^{\prime}\right)-\operatorname{aph}\left(2^{\prime \prime}\right)+\operatorname{ant}(6)-I a$ & $>2048$ & $>2048$ & $>2048$ & $>2048$ & 2048 & 64 \\
\hline & e282 & $\operatorname{aac}\left(6^{\prime}\right)-a p h\left(2^{\prime \prime}\right)+\operatorname{aph}\left(3^{\prime}\right)-I I I a$ & $>2048$ & $>2048$ & $>2048$ & $>2048$ & 128 & 16 \\
\hline & e21 & $\operatorname{ant}(6)-I a+a p h\left(3^{\prime}\right)-I I I a$ & 64 & 8 & $>2048$ & 32 & $>2048$ & 128 \\
\hline & e142 & $\operatorname{ant}(6)-I a+\operatorname{aph}\left(3^{\prime}\right)-I I I a$ & 16 & 8 & 1024 & 16 & $>2048$ & 8 \\
\hline & e308 & $\begin{array}{l}a a c\left(6^{\prime}\right)-a p h\left(2^{\prime \prime}\right)+\operatorname{ant}(6)-I a \\
+a p h\left(3^{\prime}\right)-I I I a\end{array}$ & $>2048$ & $>2048$ & $>2048$ & $>2048$ & $>2048$ & 16 \\
\hline & e68 & $\begin{array}{l}\operatorname{aac}\left(6^{\prime}\right)-\operatorname{aph}\left(2^{\prime \prime}\right)+\operatorname{ant}(6)-I a \\
\quad+\operatorname{aph}\left(3^{\prime}\right)-I I I a\end{array}$ & $>2048$ & $>2048$ & $>2048$ & $>2048$ & 2048 & 16 \\
\hline & e269 & $\begin{array}{l}\operatorname{aac}\left(6^{\prime}\right)-\operatorname{aph}\left(2^{\prime \prime}\right)+\operatorname{ant}(6)-I a \\
\quad+\operatorname{ant}(9)-I a\end{array}$ & $>2048$ & $>2048$ & $>2048$ & $>2048$ & $>2048$ & 2048 \\
\hline \multirow[t]{9}{*}{ E. faecium } & e146 & $\operatorname{aac}\left(6^{\prime}\right)-I i$ & 16 & 128 & 256 & 1024 & 64 & 64 \\
\hline & e129 & $a a c\left(6^{\prime}\right)-I i$ & $>2048$ & $>2048$ & $>2048$ & $>2048$ & 64 & 64 \\
\hline & e100 & $a a c\left(6^{\prime}\right)-I i+\operatorname{ant}(6)-I a$ & 8 & 128 & 128 & 256 & $>2048$ & 128 \\
\hline & $\mathrm{e} 30$ & $a a c\left(6^{\prime}\right)-I i+a p h\left(3^{\prime}\right)-I I I a$ & 64 & 256 & $>2048$ & 1024 & $>2048$ & 128 \\
\hline & e137 & $\operatorname{aac}\left(6^{\prime}\right)-I i+\operatorname{ant}(6)-I a+\operatorname{aph}\left(3^{\prime}\right)-I I I a$ & 32 & 256 & $>2048$ & 1024 & $>2048$ & 128 \\
\hline & e47 & $\operatorname{aac}\left(6^{\prime}\right)-I i+\operatorname{ant}(6)-I a+\operatorname{aph}\left(3^{\prime}\right)-I I I a$ & 32 & 256 & $>2048$ & 1024 & $>2048$ & 64 \\
\hline & e64 & $a a c\left(6^{\prime}\right)-I i+\operatorname{ant}(6)-I a+\operatorname{aph}\left(3^{\prime}\right)-I I I a$ & 32 & 512 & $>2048$ & 1024 & $>2048$ & 128 \\
\hline & e136 & $\begin{array}{l}a a c\left(6^{\prime}\right)-a p h\left(2^{\prime \prime}\right)+a a c\left(6^{\prime}\right)-I i \\
\quad+\operatorname{ant}(6)-I a+\operatorname{aph}\left(3^{\prime}\right)-I I I a\end{array}$ & 256 & 512 & $>2048$ & 512 & 512 & 32 \\
\hline & e185 & $\begin{array}{l}a a c\left(6^{\prime}\right)-a p h\left(2^{\prime \prime}\right)+\operatorname{ant}(6)-I a \\
+\operatorname{aac}\left(6^{\prime}\right)-I i+\operatorname{ant}(9)-I a \\
+a p h\left(3^{\prime}\right)-I I I a\end{array}$ & 2048 & $>2048$ & $>2048$ & $>2048$ & $>2048$ & $>2048$ \\
\hline \multirow[t]{2}{*}{ E. avium } & e132 & AME gene-negative & 4 & 4 & 16 & 4 & 32 & 64 \\
\hline & e149 & $\operatorname{ant}(6)-I a+\operatorname{aph}\left(3^{\prime}\right)-I I I a$ & 4 & 32 & $>2048$ & 8 & $>2048$ & 8 \\
\hline $\begin{array}{l}\text { Resistance } \\
\text { break point } \\
\text { in vitro* }\end{array}$ & & & $\geqslant 128$ & $\geqslant 128$ & $\geqslant 512$ & $\geqslant 128$ & $\geqslant 256$ & $\geqslant 256$ \\
\hline
\end{tabular}

* Resistance break points were determined based on description or susceptibility data reported previously [11, 32].

In this study, MIC more than $2000 \mu \mathrm{g} / \mathrm{ml}$ of aminoglycosides was regarded as high level resistance, as described previously $[3,13,19]$.

genes: $\operatorname{aph}\left(2^{\prime \prime}\right)-I d, \operatorname{aac}(3)-I a, \operatorname{aac}(3)-I I a, \operatorname{aac}(3)-I I I a$, $a a c(3)-I V a, a a c\left(6^{\prime}\right)-I I a, a a c\left(2^{\prime}\right)-I a$, and $\operatorname{ant}\left(2^{\prime \prime}\right)-I a$ for e129; and $\operatorname{aph}\left(3^{\prime \prime}\right)-I, \operatorname{aph}(6)-I, \operatorname{ant}\left(3^{\prime \prime}\right)(9)(\operatorname{aad} A 1)$, aadA2, aadA3, aadA4, aadA5, aadA6, and aadA7 for e6 and e30. However, none of these AME genes were detected in these strains.

\section{DISCUSSION}

Since its first emergence in late 1970s, enterococci with high level GM resistance have been disseminated in most countries and its incidence was remarkably increased in 1990s as shown in some studies $[5,20,22,23]$. Since the high level of aminoglycoside resistance is recognized as a clinically serious problem, routine examination as well as surveillance of clinical isolates of enterococci are essential for the choice of appropriate therapy and infection control. Some genes encoding AMEs, major determinants of aminoglycoside resistance of bacteria, have been identified by PCR $[10,20]$. Furthermore, in order to detect AME genes in a single strain, multiplex PCR using 
several pairs of primers in one reaction mixture was developed $[24,25]$. Using this method, prevalence of $a a c\left(6^{\prime}\right)-a p h\left(2^{\prime \prime}\right), \operatorname{aph}\left(3^{\prime}\right)-I I I a$, and $\operatorname{ant}\left(4^{\prime}\right)-I a$ were examined for enterococci, group A streptococci, and methicillin resistant $S$. aureus. In the present study, we further developed a system of the multiplex PCR for enterococci to detect six AME genes, to obtain comprehensive knowledge on prevalence of AME genes. The multiplex PCR used in this study was demonstrated to be feasible for detection and differentiation of at least six AME genes without generating non-specific product, although isolates with aph(2")Ic was not detected.

High level GM resistance in enterococci is primarily associated with $\operatorname{aac}\left(6^{\prime}\right)$-aph $\left(2^{\prime \prime}\right)$ gene encoding bifunctional enzyme $\mathrm{AAC}\left(6^{\prime}\right)-\mathrm{APH}\left(2^{\prime \prime}\right)$, which confer also resistance to clinically useful aminoglycosides (e.g. TOB, amikacin, netilmicin) [6]. The aac(6')$\operatorname{aph}\left(2^{\prime \prime}\right)$ gene is considered to have been conveyed to both enterococci and staphylococci via plasmid and transposons [5]. Incidence of recent enterococcal isolates showing high level GM resistance varies depending on countries as well as medical facilities. In a large scale survey involving 27 European countries, percentage of GM-highly resistant enterococcal isolates varied by country ranging from $1-49 \%$ (mean $22.6 \%$ ), and by species $(19.7 \%$, E. faecalis and $13.6 \%$, E. faecium) [14]. Another survey on isolates from European university hospitals reported the incidence of strains with high level GM resistance being $32 \%$ and $22 \%$ in E. faecalis and E. faecium, respectively [26]. The nationwide survey in the United States indicated the incidence of GM-highly resistant strains of $26 \%$ and $30.8 \%$ in E. faecalis and E. faecium, respectively [13]. In a study on E. faecalis isolates from a Japanese university hospital, $22.3 \%$ of isolates showed high level resistance to GM [27]. Since high level GM resistance is generally found at less than $30 \%$ of isolates as described above, the incidence $(42.5 \%)$ of $a a c\left(6^{\prime}\right)-a p h\left(2^{\prime \prime}\right)$ in E. faecalis in our present study appears to be relatively high. Considering that $a a c\left(6^{\prime}\right)$ $\operatorname{aph}\left(2^{\prime \prime}\right)$ was found in genetically distinct 18 groups of E. faecalis in our study, this AME gene is suggested to be disseminated among various clones of E. faecalis, which then spread in the university hospital where our present study was done. In contrast, the incidence of E. faecium with this AME gene was $4.3 \%$, which was markedly lower than not only that of E. faecalis in this study but also those of $E$. faecium with high level gentamicin resistance in other epidemiologic studies $[13,14]$. Our results suggested that aminoglycoside resistant E. faecium may not be a serious nosocomial pathogen, compared to E. faecalis in this hospital.

The ant(6)-Ia and aph(3')-IIIa responsible for resistance to $\mathrm{SM}$ and $\mathrm{KM}$, respectively, have been commonly found in enterococci [11]. In our present study, it was of note that ant(6)-Ia was detected together with aac $\left(6^{\prime}\right)-a p h\left(2^{\prime \prime}\right)$ in $37.6 \%$ of E. faecalis, and together with aac $\left(6^{\prime}\right)-I i$ in $53.7 \%$ of E. faecium isolates. Since E. faecalis with aac $\left(6^{\prime}\right)-\operatorname{aph}\left(2^{\prime \prime}\right)$ and ant(6)-Ia are highly resistant to both GM and SM, there will be no bactericidal regimen which is aimed at synergic activity between aminoglycosides and betalactams [3]. Similarly, E. faecium with aac(6')-Ii and ant(6)-Ia may also restrict the choice of therapy, because AAC(6')-I also reduce the synergy between beta-lactams and aminoglycosides with free $6^{\prime}$-amino groups [7]. Particularly, detection rate of E. faecalis with $\operatorname{aac}\left(6^{\prime}\right)-\operatorname{aph}\left(2^{\prime \prime}\right)$ and $\operatorname{ant}(6)-I a$ in the present study was higher than those of E. faecalis that are resistant to both GM and SM reported in other studies [12, 24]. Therefore, in our hospital, precaution should be taken for such enterococci, although enterococci with vancomycin and beta-lactam resistance are still rare in Japan [27, 28]. In addition, it was noted in our present study that a few E. faecalis strains were resistant to ampicillin without producing beta-lactamase, although the mechanism of resistance is yet to be clarified (unpublished data). These strains mostly possessed $a a c\left(6^{\prime}\right)-a p h\left(2^{\prime \prime}\right)$ together with other AME gene(s) (ant(6)-Ia, aph(3')-IIIa or ant(4')-Ia). Hence it is also important to pay attention to beta-lactam resistance in E. faecalis viewed from the significance of synergic action with aminoglycosides.

In the present study, two AME genes, ant(4')-Ia and $\operatorname{ant}(9)-I a$ which are commonly found in S. aureus were detected in a few enterococcal isolates. The ant(4')-Ia has been detected only in an E. faecalis isolate and an E. faecium isolate [11,20], and the ant(9)-Ia, encoding ANT(9)-I conferring specific by resistance to spectinomycin has never been found in enterococci. It was also noted that $\operatorname{aad}\left(3^{\prime \prime}\right)(9)(\operatorname{aad} A)$ gene which has been reported to exist in Gramnegative bacteria and $S$. aureus was recently detected in E. faecalis [10]. These findings indicated that all AME genes but aph $\left(3^{\prime \prime}\right)-I$ distributed in staphylococci have been already found in enterococci. These facts may support a view that AME genes in enterococci might have been originated from staphylococci [5].

MIC of aminoglycosides measured for representative enterococci were almost consistent with the AME gene profile revealed by multiplex PCR in this 
study. However, high level resistance to GM, SM and SPCM for three strains of e129, e30 and e6, respectively, was unexplainable by the presence of AME genes detected in this study. Furthermore, AME genes such as $\operatorname{aph}\left(2^{\prime \prime}\right)-I d$, aac(3)-Ia, $\operatorname{aph}\left(3^{\prime \prime}\right)-I$ and $\operatorname{ant}\left(3^{\prime \prime}\right)(9)$ that have been previously described in enterococci or in other bacterial species were not detected by PCR. The presence of novel AME genes or genetic variation of the known AME genes may be possible. In addition, existence of resistance mechanism other than AME including ribosomal mutation reported for SM resistance [29] have been suggested. Thus, aminoglycoside resistance mechanisms of enterococci seem to be considerably variable, and surveillance of aminoglycoside resistance as well as further analysis on resistance mechanisms seem to be all the more important.

\section{ACKNOWLEDGEMENT}

This study was supported in part by a grant (no. 09770236) from the Ministry of Education, Science and Culture of Japan.

\section{REFERENCES}

1. Murray BE. The life and times of enterococcus. Clin Microbiol Rev 1990; 3: 46-65.

2. Leclercq R. Enterococci acquire new kinds of resistance. Clin Infect Dis 1997; 24(suppl 1): S80-4.

3. Murray BE. Vancomycin-resistant enterococcal infections. N Engl J Med 1999; 342: 710-21.

4. Shaw KJ, Rather PN, Hare RS, Miller GH. Molecular genetics of aminoglycoside resistance genes and familial relationships of the aminoglycoside-modifying enzymes. Microbiol Rev 1993; 57: 138-63.

5. Simjee S, Gill MJ. Gene transfer, gentamicin resistance and enterococci. J Hosp Infect 1997; 36: 249-59.

6. Ferretti JJ, Gilmore KS, Courvalin P. Nucleotide sequence analysis of the gene specifying the bifunctional $6^{\prime}$-aminoglycoside acetyltransferase $2^{\prime \prime}$-aminoglycoside phosphotransferase enzyme in Streptococcus faecalis and identification and cloning of gene regions specifying the two activities. J Bacteriol 1986; 167: 631-8.

7. Costa Y, Galimand M, Leclercq R, Duval J, Courvalin P. Characterization of the chromosomal aac $\left(6^{\prime}\right)-I i$ gene specific for Enterococcus faecium. Antimicrob Ag Chemother 1993; 37: 1896-903.

8. Chow JW, Zervos MJ, Lerner SA, et al. A novel gentamicin resistance gene in enterococcus. Antimicrob Ag Chemother 1997; 41: 511-4.

9. Tsai SF, Zervos MJ, Clewell DB, Donabedian SM, Sahm DF, Chow JW. A new high-level gentamicin resistance gene, aph( $\left.2^{\prime \prime}\right)$-Id, in Enterococcus spp. Antimicrob Ag Chemother 1998; 42: 1229-32.

10. Clark NC, Olsvic O, Swenson JM, Spiegel CA, Tenover
FC. Detection of a streptomycin/spectinomycin adenylyltransferase gene $(\operatorname{aad} A)$ in Enterococcus faecalis. Antimicrob Ag Chemother 1999; 43: 157-60.

11. Ounissi H, Derlot E, Carlier C, Courvalin P. Gene homogeneity for aminoglycoside-modifying enzymes in gram-positive cocci. Antimicrob Ag Chemother 1990; 34: 2164-8.

12. Gordon S, Swenson JM, Hill BC, et al. Antimicrobial susceptibility patterns of common and unusual species of enterococci causing infections in the United States. J. Clin Microbiol 1992; 30: 2373-8.

13. Jones RN, Sader HS, Erwin ME, Anderson SC, Enterococcus Study Group. Emerging multiply resistant enterococci among clinical isolates. I. Prevalence data from 97 medical center surveillance study in the United States. Diagn Microbiol Infect Dis 1995; 21 : 85-93.

14. Schouten MA, Voss A, Hoogkamp-Korstanje JEE, the European VRE Study Group. Antimicrobial susceptibility patterns of enterococci causing infections in Europe. Antimicrob Ag Chemother 1999; 43: 2542-6.

15. Signoretto C, Boaretti M, Canepari P. Cloning, sequencing and expression in Escherichia coli of the low-affinity penicillin binding protein of Enterococcus faecalis. FEMS Microbiol Lett 1994; 123: 99-106.

16. Zorzi W, Zhou XY, Dardenne O, et al. Structure of the low-affinity penicillin-binding protein 5 PBP5fm in wild-type and highly penicillin-resistant strains of Enterococcus faecium. J Bacteriol 1996; 178: 4948-57.

17. National Committee for Clinical Laboratory Standards. Approved standard M7-A3. Methods for dilution antimicrobial susceptibility tests for bacteria that grow aerobically, 3rd ed. National Committee for Clinical Laboratory Standards, Villanova, Pa., 1993.

18. van Belkum A, Bax R, Peerbooms P, Goessens WHF, van Leeuwen N, Quint WGV. Comparison of phage typing and DNA fingerprinting by polymerase chain reaction for discrimination of methicillin-resistant staphylococcus aureus strains. J Clin Microbiol 1993; 31: 798-803.

19. Leclercq R, Dutka-Malen S, Brisson-Noel A, et al. Resistance of enterococci to aminoglycosides and glycopeptides. Clin Infect Dis 1992; 15: 495-501.

20. van den Braak N, van Belkum A, Kreft D, te Witt R, Verbrugh HA, Endts HP. The prevalence and clonal expansion of high-level gentamicin-resistant enterococi isolated from blood cultures in a Dutch university hospital. J Antimicrob Chemother 1999; 44: 795-8.

21. Kobayashi $\mathrm{N}, \mathrm{Wu} \mathrm{H}, \mathrm{Kojima} \mathrm{K}$, et al. Detection of $m e c A, f e m A$, and $f e m B$ genes in clinical strains of staphylococci using polymerase chain reaction. Epidemiol Infect 1994; 113: 259-66.

22. Lavery A, Rossney AS, Morrison D, Power A, Keane $\mathrm{CT}$. Incidence and detection of multi-drug-resistant enterococci in Dublin hospitals. J Med Microbiol 1997; 46: $150-6$.

23. Marcus N, Peled N, Yagupsky P. Rapid increase in the prevalence of antimicrobial drug resistance among enterococcal blood isolates in southern Israel. Eur J Clin Microbiol Infect Dis 1997; 16: 913-5. 
24. van Asselt GJ, Vliegenthart JS, Petit PLC, van de Klundert JAM, Mouton RP. High-level aminoglycoside resistance among enterococci and group A streptococci. J Antimicrob Chemother 1992; 30: 651-9.

25. Vanhoof R, Godard C, Content J, Nyssen HJ, Hannecart-Pokorni E, Belgian Study Group of Hospital Infections. Detection by polymerase chain reaction of genes encoding aminoglycoside-modifying enzymes in methicillin-resistant Staphylococcus aureus isolates of epidemic phage types. J Med Microbiol 1994; 41: 282-90.

26. Schmitz FJ, Verhoef J, Fluit AC, SENTRY Participants Group. Prevalence of aminoglycoside resistance in 20 European university hospitals participating in the European SENTRY antimicrobial surveillance programme. Eur J Clin Microbiol Infect Dis 1999; 18: 414-21.

27. Ma X, Kudo M, Takahashi A, Kanimoto K, Ike Y. Evidence of nosocomial infection in Japan caused by high-level gentamicin-resistant Enterococcus faecalis and identification of the pheromone-responsive conjugative plasmid encoding gentamicin resistance. J Clin Microbiol 1998; 36: 2460-4.

28. Hirakata Y, Yamaguchi T, Izumikawa K, et al. In vitro susceptibility studies and detection of vancomycin resistance genes in clinical isolates of enterococci in Nagasaki, Japan. Epidemiol Infect 1997; 119: 175-81.

29. Eliopoulos GM, Farber BF, Murray BE, Wennersten C, Moellering RC Jr. Ribosomal resistance of clinical enterococcal to streptomycin isolates. Antimicrob Ag Chemother 1984; 25: 398-9.

30. Matsumura M, Katakura $Y$, Imanaka $T$, Aiba $S$. Enzymatic and nucleotide sequence studies of a kanamycin-inactivating enzyme encoded by a plasmid from thermophilic bacilli in comparison with that encoded by plasmid pUB110. J Bacteriol 1984; 160: 413-20.

31. Ounissi H, Courvalin P. Appendix B. Nucleotide sequences of streptococcal genes. In: Ferretti JJ, Curtis R III, eds. Streptococcal genetics. Washington D.C: American Society for Microbiology, 1987: 275.

32. Murphy E. Nucleotide sequence of a spectinomycin adenyltransferase AAD(9) determinant from Staphylococcus aureus and its relationship to $\mathrm{AAD}\left(3^{\prime \prime}\right)(9)$. Mol Gen Genet 1985; 200: 33-9.

33. Trieu-Cuot P, Courvalin P. Nucleotide sequence of the Streptococcus faecalis plasmid gene encoding the $3^{\prime} 5^{\prime \prime}$ aminoglycoside phosphotransferase type III. Gene 1983; 23: 331-41. 